\title{
A mucus-secreting villous adenoma of the rectum
}

\author{
P. B. ROWE \\ From the Royal North Shore Hospital of Sydney, Sydney, Australia
}

EDITORIAL SYNOPSIS This is a detailed study on the protein, electrolyte, and enzymatic output of a mucus-secreting villous adenoma of the rectum in a parient who was admitted desperately ill as a result of the loss of electrolytes.

There have been sufficient case reports in the literature (McKittrick and Wheelock, 1954; Fitzgerald, 1955; Starr, Mueller and McKittrick, 1956; Cooling and Marrack, 1957; Gutierrez Blanco, 1957; Goldgraber and Kirsner, 1958; Jordan and Erickson, 1958; Frye, 1959; Hoffman, 1959; Mayfield and Milnor, 1959; Roy and Ellis, 1959; Walters, Monks, and Chitty, 1959; Rudman, Otto, and Novota, 1960; Findlay and O'Connor, 1961; Shnitka, Friedman, Kidd, and MacKenzie, 1961; Davis, Seavey, and Sessions, 1962; Magness, Spier, and Murray, 1962; Rabinowitz, Farber, and Friedman, 1962; Wells, Morgan and Cooper, 1962) to make the clinician fully aware of the interesting and potentially lethal condition of electrolyte depletion produced by the mucus-secreting villous adenoma of the rectum. Some 28 cases have been reported. All of these presented with electrolyte depletion as a result of the loss by the rectum of large quantities of mucus of high electrolyte content. Shnitka et al. (1961) have very thoroughly reviewed many of these cases. This patient, however, possesses several features worthy of report.

\section{CASE REPORT}

A 72-year-old man was admitted in 1962 with severe dehydration and hypotension, the systolic blood pressure being $50 \mathrm{~mm}$. $\mathrm{Hg}$.

In September 1945 he had undergone resection of the caecum, ascending colon, and terminal ileum for a mucoid adenocarcinoma of the caecum. Three weeks post- operatively he had begun to pass small quantities of mucus per rectum but, assuming this to be a normal sequel to his operation, failed to report it to his doctor. Over the next 17 years he remained perfectly well, except that he continued to pass ever-increasing quantities of rectal mucus.

His admission to hospital was finally precipitated by an acute influenzal illness in which he was anorexic to the extent that he did not take any food or fluid for three days at the same time continuing to pass large quantities of rectal mucus.

At the time of admission to hospital no history of abnormal fluid loss was obtained or volunteered and the patient was treated with 2 litres of intravenous normal saline which resulted in a dramatic clinical improvement.

The haematocrit was $58 \%$, haemoglobin $13.5 \%$, white cell count $13,000 /$ c.mm. (67\% neutrophils, $18 \%$ lymphocytes, $7 \%$ monocytes, and $8 \%$ band forms); serum electrolytes, (sodium $120 \mathrm{mEq} . / 1$., potassium $2.8 \mathrm{mEq} . / 1$., calcium $4.7 \mathrm{mEq}$./1., phosphorus $1.4 \mathrm{mEq}$./1., bicarbonate $16 \mathrm{mEq} . / 1$ ); blood sugar $100 \mathrm{mg} . \%$, blood urea $180 \mathrm{mg} . \%$ serum bilirubin $0.3 \mathrm{mg} . \%$; serum proteins $7.4 \mathrm{~g} . \%$ (albumin 3.8 g. $\%$, globulin 3.6 g. $\%$ ); alkaline phosphatase $8.5 \mathrm{King}$-Armstrong units.

The patient was therefore dehydrated, hyponatraemic, hypohalaemic, hypochloraemic, hypocalcaemic, acidotic, and uraemic. At this stage the history was obtained of the loss of mucus per rectum. Sigmoidoscopy revealed, and biopsy confirmed, the presence of a large mucussecreting villous adenoma of the rectum. Accordingly a number of studies on the mucus, urine, and blood of this patient were performed, and the results of two of these studies are shown in Table I. These estimations were performed when the patient was clinically well following intravenous saline and potassium therapy. The

TABLE I

BIOCHEMICAL ANALYSIS OF MUCUS, SERUM, AND URINE

\begin{tabular}{|c|c|c|c|c|c|c|c|c|}
\hline $\mathrm{Na}^{+}$ & $\begin{array}{l}K^{+} \\
(m E q . / 1 .)\end{array}$ & $\mathrm{Cl}^{-}$ & $\mathrm{HCO}_{3}$ & $\begin{array}{l}\text { Urea } \\
\text { (mg.\%) }\end{array}$ & $\begin{array}{l}\text { Glucose } \\
\text { (mg. \%) }\end{array}$ & $\begin{array}{l}\text { Uric Acid } \\
\text { (mg. \%) }\end{array}$ & $\begin{array}{l}\text { Calcium } \\
\text { (mg. \%) }\end{array}$ & $\begin{array}{l}\text { Phos- } \\
\text { phorus } \\
\text { (mg. \%) }\end{array}$ \\
\hline $\begin{array}{l}130 \\
134\end{array}$ & $\begin{array}{l}31 \\
29\end{array}$ & $\begin{array}{l}130 \\
128\end{array}$ & $\begin{array}{l}41 \\
33\end{array}$ & $\begin{array}{l}25 \\
30\end{array}$ & $\begin{array}{l}5 \\
25\end{array}$ & $\begin{array}{l}0 \cdot 2 \\
0 \cdot 1\end{array}$ & $\begin{array}{l}8 \cdot 8 \\
7.8\end{array}$ & $\begin{array}{l}3 \cdot 5 \\
2 \cdot 1\end{array}$ \\
\hline $\begin{array}{l}142 \\
138\end{array}$ & $\begin{array}{l}3 \cdot 1 \\
3 \cdot 6\end{array}$ & $\begin{array}{r}105 \\
91\end{array}$ & $\begin{array}{l}29 \\
28\end{array}$ & $\begin{array}{l}30 \\
45\end{array}$ & $\begin{array}{r}105 \\
90\end{array}$ & $\begin{array}{l}4 \cdot 0 \\
6 \cdot 0\end{array}$ & $\begin{array}{l}9 \cdot 4 \\
9 \cdot 6\end{array}$ & $\begin{array}{l}2 \cdot 5 \\
2 \cdot 4\end{array}$ \\
\hline
\end{tabular}

Urine $\begin{array}{lll}2 & (500 \mathrm{ml} .)\end{array}$

2 (470 ml.)

$\begin{array}{ll}37 & 14 \\ 28 & 17\end{array}$ 


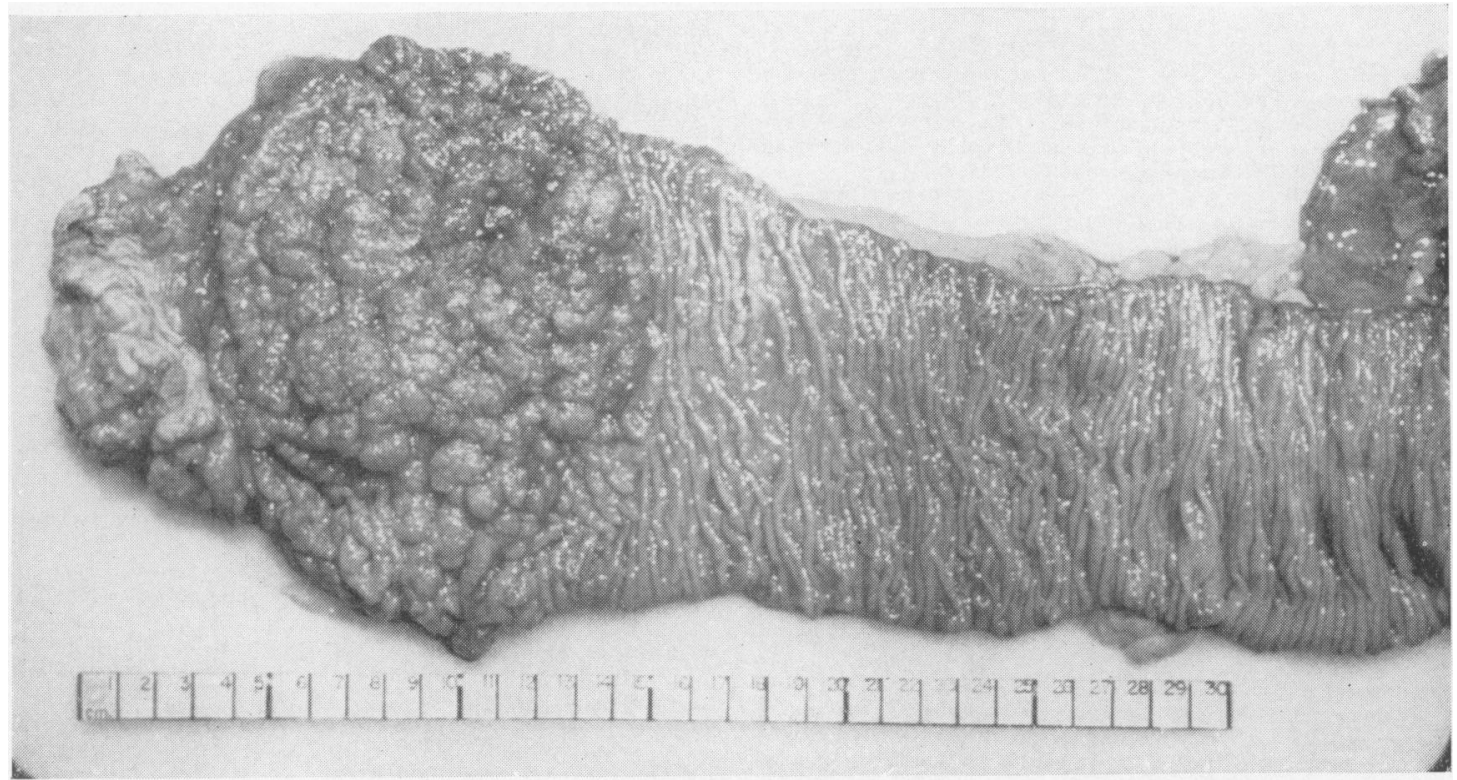

FIG. 1. Villous adenoma.

results do not show any notable variation from those obtained by other authors except for the persistent alkalosis which was noted in only one other case (Frye, 1959) which is interesting in view of the steady loss of alkaline fluid and may reflect depletion of body potassium.

A great deal of work has been done on the protein (Piper, Stiel, and Builder, 1962) and enzymatic content (Piper, personal communication) of gastric juice in normal people and in conditions such as gastric ulcer and gastric carcinoma. Accordingly, protein and enzyme estimations were performed on the tumour mucus, which had not been done before. The results are tabulated in Table II.

\section{TABLE I I}

ENZYMATIC AND PROTEIN CONTENT AND $p H$ OF TUMOUR MUCUS

\begin{tabular}{|c|c|c|}
\hline & Specimen 1 & Specimen 2 \\
\hline $\begin{array}{l}\text { Protein (mg. \%) } \\
\text { Lactic dehydrcgenase (Berger- }\end{array}$ & 106 & 82 \\
\hline Broida units) & 180 & 60 \\
\hline Alkaline phosphatase (K.-A. units) & $3 \cdot 0$ & $3 \cdot 2$ \\
\hline Acid phosphatase (K.-A. units) & $2 \cdot 3$ & 0.9 \\
\hline Amylase (Somogy units) & 30 & 50 \\
\hline $\begin{array}{l}\text { Glutamic oxaloacetic transaminase } \\
\text { (S. F. units) } \\
\text { Glutamic }\end{array}$ & $2 \cdot 5$ & 5 \\
\hline (S. F. units) & 55 & 10 \\
\hline Isocitric dehydrogenase (units/ml.) & 180 & 37 \\
\hline pH & $7 \cdot 9$ & $7 \cdot 9$ \\
\hline
\end{tabular}

The enzyme levels, generally, were lower than simultaneous serum levels. The only exception was the estimation of isocitric dehydrogenase in specimen 1 which was approximately the same as the serum level.

Electrophoresis of the mucus was also carried out and, interestingly, showed an almost identical pattern with one of those demonstrated in normal gastric juice by Piper et al. (1962) who themselves performed the analysis. They also demonstrated a persistent albumin content of $44 \%$ of the protein of the mucus. No techniques were available for accurate identification of any other serum proteins in the mucus. These observations tend to support the concept of Hollander and Horowitz (1962) that the efflux of serum proteins into the alimentary tract may be a normal phenomenon which only reaches pathological levels in conditions such as, for example, carcinoma of the stomach, giant gastric hypertrophy, and ulcerative colitis. The observations also support the theory of Soergel and Ingelfinger (1961) that serum proteins may be integral constituents of rectal and colonic mucus.

The loss of albumin per rectum in this patient ranged between 563 and $653 \mathrm{mg}$. per day, a loss for which he could adequately compensate.

When these studies were completed the patient underwent laparotomy. At operation a large villous adenoma $(11 \mathrm{~cm}$. by $15 \mathrm{~cm}$.) was found in the rectum (Fig. 1), but sections showed no evidence of malignant change.

A carcinoma was also found in the colon near the site of the anastomosis performed 17 years earlier. Histological examination showed it to be an adenocarcinoma which had spread to the regional lymph nodes. In view of the dual pathology a combined total colectomy and abdomino-perineal resection was performed from which the patient made a satisfactory recovery.

I would like to thank Dr. R. G. Epps and Mr. L. S. Loewenthal for permission to publish this case, Dr. D. W. Piper for his helpful advice and criticism, and Dr. F. J. Radcliffe and Miss J. E. Builder for their technical assistance. 


\section{REFERENCES}

Cooling, C., and Marrack, D. (1957). Potassium-secreting tumour of the colon. Proc. roy. Soc. Med., 50, 272-274.

Davis, J. E., Seavey, P. W., and Sessions, J. T., Jr. (1962). Villous adenomas of the rectum and sigmoid colon with severe fluid and electrolyte depletion. Ann. Surg., 155, 806-812.

Findlay, C. W. Jr., and O'Connor, T. F. (1961). Villous adenomas of the large intestine with fluid and electrolyte depletion. J. Amer. med. Ass., 176, 404-408.

Fitzgerald, M. G. (1955). Extreme fluid and electrolyte loss due to villous papilloma of the rectum. Brit. med.J., 1, 831-832.

Frye, T. R. (1959). Villous adenoma of the sigmoid colon. Radiology, $73,71-75$.

Goldgraber, M. B., and Kirsner, J. B. (1958). Papilloma of the large intestine; a clinical-pathologic correlation. Gastroenterology, $35,36-49$.

Gutierrez Blanco, H. (1957). Hiperazohernia extrarrenal por tumor velloso rectal hipersecretante; communicación de dos observaciones. Arch. urug. Med., 50, 184-196.

Hoffman, E. (1959). Hyponatremia due to a villous adenoma of the rectosigmoid. Amer. J. Surg., 98, 99-104.

Hollander, F., and Horowitz, M. I. (1962). Serum proteins in gastric mucus and other secretions. Gastroenterology, 43, 75-83.

Jordan, G. L., Jr., and Erickson, E. (1958). Villous papilloma of the rectum with severe fluid and electrolyte depletion. Arch. Surg., 77, 248-252.

McKittrick, L. S., and Wheelock, F. C., Jr. (1954). Carcinoma of the Colon, pp. 61-63. Thomas, Springfield, Illinois.

Magness, J. L., Spier, J. J., and Murray, J. B. (1962). Villous adenoma of the rectum with electrolyte depletion simulating adrenal insufficiency. Lancet, 82, 250-254.
Mayfield, L. H., and Milnor, J. P., Jr. (1959). Villous tumor of the rectum and a portion of the sigmoid flexure causing severe electrolyte imbalance. Dis. Colon Rect., 2, 311-313.

Piper, D. W. Personal communication.

- Stiel, M. C., and Builder, J. E. (1962). The electrophoresis of human gastric juice. Gut, 3, 349-360.

Rabinowitz, P., Farber, M., and Friedman, I. S. (1962). A depletion syndrome in villous adenoma of the rectum. Arch. intern. Med., 109, 265-269.

Roy, A. D., and Ellis, H. (1959). Potassium-secreting tumours of the large intestine. Lancet, 1, 759-760.

Rudman, I., Otto, C., and Novota, O. J. (1960). Villous papilloma of the rectum causing massive electrolyte losses. Arch. Surg., 81, 140-142.

Shnitka, T. K., Friedman, M. H. W., Kidd, E. G., and MacKenzie, W. C. (1961). Villous tumors of the rectum and colon characterized by severe fluid and elestrolyte loss. Surg. Gynec. Obstet., $112,609-621$.

Starr, A., Mueller, S., and McKittrick, J. R. (1956). Villous adenoma of the colon associated with severe hypopotassemia. Arch. Surg., 73, 995-998.

Soergel, K. H., and Ingelfinger, F. J. (1961). Proteins in serum and rectal mucus of patients with ulcerative colitis. Gastroenterology 40, 1, 37-46.

Walters, G., Monks, P. J. W., and Chitty, K. (1959). Metabolic disturbance due to villous papilloma of the rectum. Brit. J. Surg., 47, 177-178.

Wells, C. L., Morgan, T. J., and Cooper, W. M. (1962). Villous tumors of the rectosigmoid colon with severe electrolyte imbalance. Amer. J. clin. Path., 37, 507-514. 